\title{
GAMBARAN PENERIMAAN DIRI SISWA YANG MENGALAMI PERCERAIAN ORANGTUA
}

\author{
Dona Dyah Kusumawardhani ${ }^{1}$ \\ Michiko Mamesah ${ }^{2}$
}

\begin{abstract}
Abstrak
Penelitian ini Bertujuan untuk mengetahui gambaran penerimaan diri remaja yang mengalami perceraian orangtua yang dialami oleh siswa Sekolah Menengah Atas di SMAN 14 Jakarta. Tema penelitian ini memfokuskan pada gambaran penerimaan diri, dampak perceraian orangtua terhadap remaja dan faktor yang berpengaruh terhadap penerimaan diri. Pengambilan sampel menggunakan teknik critical case study berjumlah 2 orang. Penelitian ini bersifat kualitatif deskriptif dengan metode riset naratif (narrative research). Pengumpulan data melakukan wawancara mendalam (in depth interview) secara online, observasi melalui video call dan call whatsapp serta studi dokumentasi. Data tersebut didukung dengan data tambahan dari wawancara Guru BK, Wali kelas, dan Teman Sebaya. Hasil penelitian ini menyimpulkan bahwa siswa yang mengalami perceraian orangtua memiliki penerimaan diri yang cukup baik mereka mampu belajar dari perceraian yang orangtua yang mereka alami. Mereka memiliki permasalahan masing-masing disekolah yaitu pencapaian akademik yang rendah pada responden perempuan dan pergi dari mata pelajaran pada responden laki-laki. Namun di masa sekarang mereka sudah belajar dari perceraian orangtua mereka dan menjadi kekuatan untuk bangkit dari perceraian orangtua mereka.
\end{abstract}

Kata Kunci: Penerimaan diri, Siswa, Perceraian Orangtua

\begin{abstract}
This study aims to describe the self-acceptance of adolescents who experience parental divorce experienced by high school students at SMAN 14 Jakarta. The theme of this research focuses on the picture of self-acceptance, the impact of parental divorce on adolescents, and the factors that influence self-acceptance. Sampling using a purposive sampling technique amounted to 2 people. This research is a qualitative descriptive with a narrative research. Data collection conducted indepth interviews (in-depth interviews) online, observation via video call and WhatsApp call, and documentation study. This data is supported by additional data from interviews with counseling teachers, homeroom teachers, and peers. The results of this study concluded that students who experienced parental divorce had good enough self-acceptance that they were able to learn from their parents' divorce. They have their respective problems in school, namely low academic achievement for female respondents and moving away from subjects for male respondents. But in the present they have learned from their divorce parents and become the strength to rise from their parents' divorce.
\end{abstract}

Key words: Self-acceptance, Student, Parental Divorce

\footnotetext{
${ }^{1}$ Universitas Negeri Jakarta, donadyahkusumawardhani_1715163842@mhs.unj.ac.id

${ }^{2}$ Universitas Negeri Jakarta, mmamesah@unj.ac.id
} 


\section{PENDAHULUAN}

Keluarga adalah lembaga pertama bagi anak, yaitu sebagai tempat bagi anak untuk bersosialisasi, memperoleh kasih sayang, simpati, pembelajaran, bimbingan, pendidikan, sandang, serta papan. Tidak hanya aspek materiel pada keluarga, anak pun wajib mendapatkan afeksi yang cukup dari orangtua agar kebutuhan psikologis dan morelnya terpenuhi. Namun pada masyarakat urban, orangtua kini sering menghadapi banyak persoalan seperti yang dikatakan oleh Nasir (2012) berupa kurangnya kedewasaan pasangan suami istri, faktor ekonomi, terjadinya kesalahpahaman pemikiran, perbedaan pendapat, keseharian, dan emosi yang beragam memicu adanya perpisahan atau perceraian, sehingga mengakibatkan angka perceraian meningkat.

Faktanya, perceraian sudah lumrah pada masyarakat khususnya masyarakat urban. Fenomena perceraian pun kini semakin sering diberitakan melalui media massa, baik melalui televisi, media cetak, maupun berita online. Berdasarkan data yang dikutip dari situs berita online detik.com dari website Mahkamah Agung (MA), Rabu (3/4/2019), sebanyak sebanyak 419.268 pasangan bercerai sepanjang 2018 .

Dari jumlah itu, inisiatif perceraian paling banyak dari pihak perempuan yaitu 307.778 perempuan. Sedangkan dari pihak laki-laki sebanyak 111.490 orang. Pada tahun 2015-2019, terdapat 23.759 kasus yang tercatat di Pengadilan Agama Jakarta Timur terkait perkara perceraian. Kasus tersebut disebabkan oleh cerai talak dan cerai gugatan, sehingga dalam hal ini perceraian orangtua di Jakarta cukup marak terjadi.
Keluarga yang telah terbentuk tidak jarang harus berakhir dengan perceraian, perceraian merupakan akhir dari eskalasi berbagai permasalahan yang terjadi sebelumnya dan merupakan jalan terakhir yang harus ditempuh jika pernikahan sudah tidak dapat dipertahankan lagi (Dariyo, 2007).

Perceraian pada orangtua tidak hanya berdampak pada kedua pasangan yang bercerai, tetapi anak juga dapat merasakan dampak dari perceraian orangtua, khususnya pada usia remaja. Hal ini dikarenakan masa remaja merupakan periode yang penting dimana terjadi perkembangan fisik dan perkembangan mental (Wangge \& Hartini, 2013). Keseluruhan perkembangan tersebut membutuhkan penyesuaian mental dan pembentukan sikap, nilai, dan minat baru (Hurlock, 2006). Remaja berada pada masa kritis karena sedang berhadapan dan memenuhi tugas perkembangannya. Pada saat tersebut, remaja yang mengalami perceraian orangtua harus berhadapan dengan fakta bahwa kedua orangtuanya berpisah, hal ini membuat mereka memiliki beban ganda yaitu memenuhi tugas perkembangan dan menghadapi perceraian yang dialami oleh orangtua.

Keadaan tersebut berhubungan dengan penerimaan diri remaja dalam merefleksi dirinya sendiri, maupun bagaimana dirinya memahami fenomena perceraian. Penerimaan sikap orang lain dipengaruhi oleh sikap menerima diri sendiri yang timbul dari penyesuaian pribadi maupun penyesuaian lingkungan sosial yang baik. Berkaitan dengan hal tersebut, Williams dan Lynn dalam Bernard (2013) menyebutkan bahwa penerimaan diri mempunyai lima cara yang berbeda, meliputi sikap tidak terikat (nonattachment), sikap tidak 
menghindar (non-avoidance), tidak menuduh (nonjudgement), toleransi (tolerance) dan memiliki kemauan (willingness). Lebih lanjut, Simon et al. (2016) mengatakan "Kebahagiaan banyak bergantung pada sikap menerima dan menikmati keadaan orang lain dan apa yang individu miliki, serta mempertahankan keseimbangan antara harapan dan prestasi. Berkaitan dengan penerimaan diri sendiri, remaja perlu memiliki perasaan untuk menyukai dan menerima diri sendiri, maupun perasaan bahwa mereka diterima oleh lingkungannya. Hal ini dapat membantu mereka puas dengan kehidupannya, sehingga dapat menganggap dirinya bahagia.

Hal ini berhubungan dengan teori keluarga seperti yang disebutkan oleh Micucci (2009). Teori sistem keluarga dibangun berdasarkan pola pikir bahwa keluarga terdiri dari banyak anggota yang memiliki karakteristik tertentu. Salah satu dari karakteristik yang ada, bahwa anggota keluarga saling memengaruhi satu sama lain. Pengaruh ini terjadi dengan dinamika yang ada sehingga tidak mungkin untuk diidentifikasikan sebab dan akibatnya.

Oleh karena itu, perceraian orangtua dapat memengaruhi pemenuhan kebutuhan serta penerimaan diri anak karena dinamika dalam keluarga dapat berubah, seperti hak asuh, anak tinggal hanya bersama dengan ibu atau ayah yang memengaruhi interaksi satu sama lain antara ayah, ibu, dan anak.

Perceraian orangtua tidak selalu berdampak negatif, banyak kasus perceraian yang menjadi solusi agar pasangan suami-istri tidak lagi menyakiti satu sama lain dan juga anak-anak mereka yang nantinya tidak akan menjadi korban dari ketidakharmonisan sebuah pernikahan, sehingga penerimaan diri remaja yang mengalami perceraian orangtua dapat diukur karena memiliki dua dampak yang akan dialami oleh remaja, yaitu penerimaan diri positif dan penerimaan diri negatif.

Peneliti melakukan studi pendahuluan yang berkaitan dengan penerimaan diri remaja yang mengalami perceraian orangtua di SMAN 14 Jakarta dengan subjek empat belas siswa. Hasil studi pendahuluan menunjukkan bahwa sebanyak $92 \%$ subjek memilih pernyataan positif yang dapat dilihat melalui item nomor lima yang menyatakan perceraian orangtua yang mereka alami menjadikan mereka lebih kuat dan item nomor tiga belas yang menyatakan perceraian orangtua membuat subjek optimis menjalani kehidupan seharbernardi-hari. Pada hasil yang sama yaitu $92 \%$ subjek memilih pernyataan negatif pada item nomer dua belas yang menyatakan subjek merasa rendah diri setelah perceraian orangtua yang mereka alami. Kesimpulan dari hasil studi pendahuluan di atas siswa memiliki dampak yang positif dan negatif terhadap perceraian yang dialami oleh orangtua mereka sehingga butuh diketahui lebih lanjut mengenai penerimaan diri siswa SMAN 14 Jakarta yang mengalami perceraian orangtua.

Berdasarkan fenomena dan pernyataan diatas, Siswa yang mengalami perceraian orangtua di SMAN 14 Jakarta perlu diketahui penerimaan dirinya apakah memiliki penerimaan diri yang positif atau negatif. Jika hal ini telah diketahui guru BK di sekolah dan orangtua lebih mudah untuk memahami dan menghadapi siswa yang mengalami perceraian orangtua sehingga siswa memiliki sifat dan sikap yang positif terhadap diri sendiri agar ke 
depannya mereka menjadi manusia yang utuh dan berbahagia.

\section{Pengertian Penerimaan diri}

Penerimaan diri menurut Hurlock (2006) adalah suatu tingkat kemampuan dan keinginan individu untuk hidup dengan segala karakteristiknya. Germer (2009) menyebutkan penerimaan diri adalah kemampuan individu untuk dapat memiliki pandangan yang positif mengenai pengenalan diri yang tidak dapat muncul dengan sendirinya, melainkan harus dikembangkan oleh diri sendiri. Individu yang dapat menerima dirinya diartikan sebagai individu yang tidak bermasalah dengan dirinya sendiri dan tidak memiliki beban perasaan terhadap diri sendiri, sehingga individu lebih banyak memiliki kesempatan untuk bereksplorasi dengan lingkungan dan orang lain di sekitarnya. Sheerer dalam Machdan dan Hartini (2012) menyebutkan penerimaan diri adalah sikap dalam menerima diri dan keadaannya secara objektif, menerima kelebihan, maupun kelemahannya. Menerima diri berarti memahami dan telah menyadari keinginan, kemampuan, kekurangan, dan kelebihan untuk bertanggung jawab dalam mengembangkan diri untuk menjadi individu yang lebih baik setiap harinya.

Ellis dalam Ely (2013) menyebutkan konsep penerimaan diri juga dikenal sebagai Unconditional Self Acceptance (USA). Individu yang memiliki penerimaan diri tanpa syarat cenderung tidak merasa cemas ketika menerima kritik dan saran dari orang lain. Selain itu, individu tersebut dapat bertindak sesuai keinginannya tanpa meminta persetujuan dari orang lain, tetapi tetap bertanggung jawab terhadap hal yang dilakukan dan dirasakan olehnya. Dengan demikian, arti penerimaan diri dapat disimpulkan sebagai cara individu dalam memandang diri sendiri yang berdampak pada emosi yang akan ditimbulkan.

Penerimaan diri memiliki keterkaitan dengan kekuatan karakter. Individu memiliki kualitas khusus yang relatif stabil dari waktu ke waktu dalam berbagai situasi. Remaja dapat menyadari dan mengapresiasi dirinya terhadap karakter positif yang dimiliki dan terdorong untuk mengembangkan berbagai potensi, seperti kepribadian, bakat, keluarga, agama, karakteristik budaya. Di samping itu, remaja yang memiliki penerimaan diri lebih mampu untuk menghadapi peristiwa negatif yang terjadi pada dirinya, seperti kritik atau penolakan diri dari orang lain.

Penerimaan diri dapat memunculkan emosi positif, hubungan negatif yang memuaskan, serta mendorong individu untuk dapat beradaptasi ketika mengalami peristiwa negatif (Bernard M. E., 2013). Pemahaman individu akan semakin meningkat jika individu dapat lebih terbuka terhadap pengalaman hidup yang dialaminya. Penerimaan diri menjadi aspek penting yang perlu dimiliki oleh remaja karena berkaitan dengan kemampuan individu dalam memandang dirinya dan menyesuaikan diri dalam lingkungan sosialnya.Tuliskan deskripsi teori menurut ahli yang digunakan dalam penelitian.

Faktor-Faktor Penerimaan Diri : Menurut (Hurlock, 2006) penerimaan diri dibentuk oleh Pemahaman diri (Self Understanding), Harapan yang realistis (Realistic Aspiration), Tidak adanya hambatan dari lingkungan (Absence of Environment Obstacles), Sikap sosial yang positif (Social Insight), Identifikasi dengan orang yang memiliki 
penyesuaian diri yang baik, Pola asuh yang baik pada masa anak-anak, Konsep diri yang stabil (Stable Self Concept).

\section{Pemahaman diri (Self}

Understanding) merupakan hal asli yang muncul dengan tanda keaslian, realita, dan kejujuran. Semakin seseorang memahami dirinya, semakin baik penerimaan dirinya.

Harapan yang realistis (Realistic Aspiration) Ketika seseorang memiliki harapan yang realistis dalam mencapai sesuatu, keadaan ini dapat memengaruhi kepuasan diri yang merupakan esensi dari penerimaan diri. Harapan akan menjadi realistis jika dibuat sendiri oleh diri sendiri yang akan dihasilkan dari penerimaan diri.

Tidak adanya hambatan dari lingkungan (Absence of Environment Obstacles) Hambatan dari lingkungan seperti diskriminasi ras, jenis kelamin, atau agama menghasilkan individu tidak mencapai penerimaan diri karena terpengaruh dari interpersonal. Apabila hambatan itu dihilangkan dan jika keluarga, teman sebaya, atau orangorang yang berada di sekelilingnya memberikan motivasi dalam mencapai tujuan, seseorang akan mampu memperoleh kepuasan terhadap pencapaiannya.

Sikap sosial yang positif (Social Insight) Terdapat tiga kondisi utama yang menghasilkan evaluasi positif, yaitu tidak adanya prasangka terhadap seseorang, adanya penghargaan terhadap kemampuan-kemampuan sosial, dan kesediaan individu untuk mengikuti tradisi suatu kelompok sosial. Jika seseorang telah memperoleh sikap sosial yang positif, ia akan lebih mampu menerima dirinya.

Identifikasi dengan orang yang memiliki penyesuaian diri yang baik
Sikap ini akan menghasilkan penilaian diri yang positif dan penerimaan diri. Proses identifikasi yang paling kuat terjadi pada masa kanak-kanak.

Pola asuh yang baik pada masa anakanak Individu dipengaruhi oleh pola asuh karena selama hidupnya anak lebih banyak berinteraksi di rumah daripada di luar rumah, sehingga pendidikan di rumah dan sekolah sangat memengaruhi kehidupan anak.

Konsep diri yang stabil (Stable Self Concept) Konsep diri yang positif mampu mengarahkan seseorang untuk melihat dirinya secara konsisten.

\section{Remaja}

Masa remaja merupakan masa transisi dari masa anak-anak menuju masa dewasa. Dalam masa perkembangan ini, banyak perubahan yang terjadi dalam diri seorang individu. Setiap individu tersebut akan mengalami perubahan secara fisik maupun psikis. Dapat disimpulkan bahwa remaja berada pada tahap yang rentan karena sedang berada pada masa perkembangan yang mudah berubah. Krisnani dan Farakhiyah (2010).

Menurut Marliani (2016), remaja berada pada periode transisi antara masa anak-anak ke masa. Pada masa remaja, individu memiliki masalah yang lebih kompleks, misalnya lebih sensitif pada perasaan yang dimiliki dan lebih susah diatur. Masa tersebut dapat dikatakan bahwa seseorang lebih rebel untuk dihadapi. Sebagai orangtua, diperlukan kesadaran untuk memberikan perlakuan khusus serta usaha yang lebih tinggi dalam menghadapi remaja.

Remaja yang berada pada tahap transisi dari anak-anak menuju dewasa memerlukan perhatian yang khusus dan lingkungan yang siap untuk menjelaskan berbagai perubahan yang dialami oleh 
mereka, sehingga mereka memerlukan keberadaan orang dewasa.

\section{Tugas Perkembangan}

Marliani (2016) menjelaskan tugas perkembangan adalah hal-hal yang muncul untuk dipenuhi dan dijalani oleh individu pada periode tertentu sesuai dengan umur individu dan sesuai dengan fase perkembangan yang sedang dimiliki. Tugas perkembangan berkaitan erat dengan perubahan kematangan, persekolahan, pekerjaan, pengalaman beragama, dan hal lainnya sebagai himpunan untuk pemenuhan dan kebahagiaan hidupnya. Keberhasilan dalam menyelesaikan tugas perkembangan pada fase tertentu akan memperlancar ketika menghadapi tahap berikutnya. Di samping itu, remaja memiliki tugas perkembangan yang menuntutnya untuk dapat menyesuaikan diri dalam lingkungan dan tantangan hidup yang ada di hadapannya.

Jika remaja dalam memenuhi tugas perkembangannya mengalami permasalahan akan menimbulkan :

Perubahan perilaku kekanakkanakan menjadi sikap yang terus dimiliki hingga dewasa dan perilaku dewasa tidak dapat dicapai dengan mudah Kesulitan dalam menerima perubahan fisik yang dialami.

Mengalami kesulitan dalam mencapai kemandirian yang berakibat memunculkan perilaku yang buruk.

Remaja gagal untuk memiliki harapan untuk berdiri sendiri, sehingga penyesuaian sosial merupakan salah satu hal yang sulit dihadapi oleh remaja.

Norma dan nilai yang berlaku sulit dipahami serta memiliki kegagalan dalam menghadapi perbedaan norma dan nilai yang dianut, sehingga remaja seringkali disebut sebagai "anak nakal".

\section{Arti Keluarga pada Masa Remaja}

Masa remaja adalah masa yang paling rentan karena pada masa ini individu sedang berada pada peralihan dari masa anak-anak menuju dewasa. Pada masa ini, banyak hal yang menjadi perhatian remaja, seperti aspirasi karier, cita-cita, keberlangsungan hidup, dan memandang suatu hal dalam berbagai perspektif. Dari sekian banyak hal faktor yang mendukung tumbuh kembang remaja, keluarga menjadi unsur yang sangat penting untuk mendukung mereka dalam menghadapi masa transisi ini.

Seorang psikolog Roslina Verauli (2018) menjelaskan bahwa keberadaan keluarga adalah hal yang sangat penting dalam memengaruhi aspek psikologis untuk mendukung anak menemukan jati dirinya, sehingga ketika anak menghadapi perceraian orangtua, remaja dapat lebih cepat untuk melihat perubahan yang terjadi dalam keluarga. Remaja pun perlu untuk diberikan pemahaman, dikuatkan dan didukung ketika menghadapi perubahan yang ada pada keluarganya dalam proses atau pasca perceraian.

Lalu, menurut Maryam dalam Gunarsa dan Gunarsa (2008), sebagai seorang anak dalam pertumbuhan dan perkembangannya sangat dipengaruhi oleh Orangtua, karena Orangtualah yang memiliki tanggung jawab dalam seluruh eksistensi anak, baik secara fisik maupun psikis, untuk tumbuh dan berkembang menjadi manusia yang matang dan harmonis. Hal ini hanya dapat dicapai jika kedua Orangtua dalam keadaan hubungan yang harmonis, yaitu suasana yang penuh kehangatan, keakraban, saling pengertian, memiliki toleransi dan menghargai yang tinggi.

Keluarga memiliki peranan penting dalam kehidupan remaja. Figur orangtua 
memiliki arti sebagai sumber penting timbulnya pemahaman diri anak, dan menjadi figur kelekatan utama bagi anak (Elliot, 2009). Selain itu, orangtua turut membantu untuk memenuhi kebutuhan remaja dengan cara menjadi contoh yang baik dalam bersikap dan berperilaku. Pertumbuhan anak sangat tergantung pada bagaimana anak memperoleh informasi, afirmasi, maupun kebutuhan hidup yang tercukupi. Apabila keluarga memiliki konflik hingga mengakibatkan perceraian, keadaan ini akan memengaruhi remaja dalam membentuk pribadi dan penerimaan diri remaja.

\section{Perceraian}

Kata "cerai" dalam Kamus Besar Bahasa Indonesia (KBBI) berarti pisah, putus hubungan sebagai suami istri. Sementara "perceraian" mengandung arti perpecahan, sehingga dapat disimpulkan "perceraian" berarti putusnya hubungan sebagai suami istri (Syaifuddin, Turatmiyah, \& Yahanan, 2013).

(Puspitorini, 2019) menjelaskan bahwa secara hukum perceraian di Indonesia yang dikabulkan oleh pengadilan memiliki ketentuan yang meliputi, adanya penganiayaan baik fisik maupun psikis, adanya cacat biologis, hukuman yang diterima oleh salah satu pihak, adanya ketidakharmonisan dalam rumah tangga, ataupun adanya perbuatan amoral. Dengan kata lain pernikahan yang tidak menimbulkan kebahagiaan segera diakhiri agar permasalahan tidak berlarut.

Dari berbagai masalah tersebut terjadilah konflik keluarga. Lestari (2012) menyebutkan bahwa konflik mencerminkan adanya ketidakcocokan, baik ketidakcocokan yang berlawanan maupun karena perbedaan. Konflik bersumber pada perbedaan nilai, identitas, kesalahan persepsi, dan kesalahan komunikasi. Konflik turut berperan pada proses evolusi ketidakcocokan dalam hubungan. Maka dari itu, gagalnya persamaan dan komunikasi tersebut dapat menimbulkan berbagai kesalahpahaman, sehingga konflik yang awalnya sederhana menjadi berlarut.

Konflik mungkin akan menyebabkan munculnya emosi negatif, seperti jengkel, marah, atau takut. Akan tetapi, akhir dari keberadaan konflik akan menimbulkan dua sifat, yaitu konstruktif dan destruktif. Jika konflik tidak dihadapi dengan baik, akan menimbulkan sakit bagi orang yang mengalaminya. Sehingga, seringkali pasangan dan keluarga yang terusmenerus berada dalam konflik akan berpikir untuk mengatasi konflik dengan cara bercerai.

Perceraian adalah hal terakhir yang harus ditempuh ketika pernikahan tidak lagi mencapai tujuan-tujuan yang sudah disusun atau tidak lagi menuju pada kebahagiaan.

\section{Dampak Perceraian pada Remaja}

Pada dasarnya di dalam hati anak, mereka sangat membutuhkan sosok orangtua yang utuh, sehingga anak sangat ingin kedua orangtua tetap bersama, namun anak dipaksa untuk menerima kenyataan bahwa ekspektasi orangtuanya tetap bersama tidak dapat terpenuhi.

Pada keluarga yang bercerai dengan proses yang baik, anak mungkin akan lebih memiliki penerimaan diri yang baik dan dampak positif yang ditimbulkan kepada anak lebih baik untuk lebih berhati-hati dalam memilih pasangan di kehidupan yang akan mereka akan lalui,. Akan tetapi pada keluarga yang bercerai dengan proses 
yang buruk, memungkinkan anak untuk memiliki pandangan yang buruk terhadap kehidupan berpasangan dan tidak optimis untuk menghadapi kehidupan yang akan dilalui. Di samping itu, penerimaan diri akan sangat memengaruhi kehidupan pribadi dan sosial remaja karena cara remaja memandang dirinya sangat dipengaruhi oleh apa yang mereka hadapi khususnya dalam keluarga dan peran orangtua.

Perceraian yang marak terjadi di kalangan masyarakat urban dapat memiliki dampak pada anak. Hal tersebut tidak hanya mengakibatkan perpisahan kedua orangtua, tetapi juga dampak psikis yang dirasakan oleh anak seperti kurang puas dengan kehidupan yang dimiliki karena melihat orangtuanya bercerai, lebih rentan memiliki gejala depresi dan kecemaafin dengan terlalu berat memikirkan masalah yang ada dalam keluarganya sehingga membuat harga diri yang lebih rendah.

Hal ini akan sangat memengaruhi penerimaan diri yang dimiliki oleh remaja karena keberadaan orangtua yang tidak lengkap setelah perceraian orangtua dan pemahaman diri terhadap perceraian yang terjadi oleh orangtua mereka berdampak pada perasaan dicintai dan memiliki oleh anak.

\section{METODE PENELITIAN}

Pada penelitian ini, Peneliti memilih jenis penelitian dengan pendekatan kualitatif. Menurut Bauman dan Adair dalam Badrujaman (2015) penelitian kualitatif dirancang untuk meneliti tingkah laku manusia dan maknanya serta dampak dari konteks pandangan secara sosial dalam tingkah laku yang dihasilkan.
Kemudian metode yang digunakan dalam penelitian ini adalah deskriptif. Penelitian deskriptif adalah suatu metode penelitian yang dilakukan untuk menggambarkan fenomena - fenomena yang ada dan berlangsung saat ini ataupun saat yang lampau.

Naratif adalah istilah yang diberikan untuk teks atau wacana yang digunakan dalam konteks mendalam pada penelitian kualitatif (Chase, 2005), dengan fokus khusus pada cerita yang diceritakan oleh individu (Polkinghorne, 1995) Sebagai sebuah metode, penelitian ini dimulai dengan pengalaman yang diekspresikan dalam kehidupan dan cerita individu. (Creswell, 2007)

Alasan peneliti menggunakan strategi narrative research yaitu karena peneliti ingin mengetahui penerimaan diri siswa SMAN 14 Jakarta yang mengalami perceraian orangtua berdasarkan pengalaman pribadi yang dirasakan oleh informan.

Teknik pengambilan Informan yang digunakan dalam penelitian ini adalah critical case sampling. Selain karena metode sampling ini direkomendasikan ketika menggunakan narrative research, critical case sampling bertujuan untuk mendapatkan informasi yang maksimal pada kasus tertentu. (Creswell, 2007) menuturkan, Prosedur untuk melaksanakan penelitian ini terdiri dari fokus pada studi satu atau dua individu, mengumpulkan data melalui pengumpulan cerita mereka, mengidentifikasi pengalaman individu, dan secara urutan kronologis serta makna dari pengalaman tersebut.

Informan dalam penelitian ini mempunyai kriteria sebagai berikut :

1. Siswa/i SMA Negeri 14 Jakarta

2. Berada pada usia remaja (13-16 tahun) 
3. Merupakan anak yang mengalami perceraian orangtua secara hukum negara.

Prosedur pengumpulan data yang digunakan adalan wawancara mandalam (in depth interview) dan studi dokumentasi

Tahap selanjutnya adalah menganalisa data yang telah didapatkan dari Informan di SMA Negeri 14 Jakarta. Peneliti mencari dan menyusun informasi dan data yang telah diperoleh dari hasil wawancara, catatan lapangan, dan dokumentasi yang telah didapatkan dengan cara mengorganisasikan ke dalam kategori, menjabarkan, dan melakukan sistesis serta membuat kesimpulan sehingga dapat dipahami oleh diri sendiri maupun orang lain.

Peneliti menganalisis data mulai dari sebelum memasuki lapangan, selama di lapangan, dan setelah selesai di lapangan. Data yang telah didapatkan dianalisis secara kualitatif. Analisis data setelah pengumpulan data dilakukan dengan: (1) Organisasi data, (2) reduksi data, (3) penyajian tampilan, (4) verifikasi data.

Teknik pemeriksaan/pengecekan keabsahan data dalam penelitian ini menggunakan teknik triangulasi. Pada penelitian ini, teknik triangulasi data yang dipergunakan adalah triangulasi sumber. Triangulasi sumber adalah cara membandingkan dan mengecek kembali kebenaran sebuah informasi yang diperoleh melalui cara yang berbeda dalam penelitian kualitatif.

Hal ini dilakukan sebagai berikut :

Membandingkan data hasil pengamatan dengan hasil wawancara, Membandingkan informasi yang didapati melalui sumber data dengan metode yang sama. Sumber data adalah
Informan, teman sebaya, guru BK dan wali kelas.

\section{HASIL PENELITIAN}

Berdasarkan hasil penelitian, bahwa terdapat beberapa gambaran penerimaan diri pada siswa yang mengalami perceraian orangtua yaitu tidak menyalahkan diri sendiri atas kesalahan yang dilakukan oleh orangtua mereka dan dapat belajar dari perceraian orangtua mereka; berpikir positif dan realistis; Memiliki kesadaran diri; menghargai karakteristik positif mereka, dan mengembangkan potensi Keinginan untuk menerima fakta dan kondisi hidupnya baik menguntungkan maupun tidak menguntungkan dengan jujur dan sebijaksana; memiliki perasaan layak untuk bahagia; mampu mengetahui, memahami dan memperbaiki kelemahan diri; dan individu mampu mengetahui bahwa dirinya dapat memberi dan menerima persahabatan dan kasih sayang.

Pada penelitian ini, peneliti juga menemukan bahwa terdapat 7 faktor yang memegaruhi gambaran penerimaan diri siswa yang mengalami perceraian orangtua yaitu pemahaman diri, harapan yang realistis, tidak adanya hambatan dari lingkungan, sikap sosial yang positif, identifikasi dengan orang yang memiliki penyesuaian diri yang baik, pola asuh yang baik pada masa anakanak.

Adapun keterbatasan mengerjakan penelitian, antara lain : Sulit mencari data siswa yang mengalami perceraian orangtua, Penelitian ini dilakukan dengan metode kualitatif dan menggunakan data primer yang didapatkan melalui wawancara mendalam hal ini meliputi subyektifitas peneliti, sehingga penelitian ini bergantung pada interpretasi peneliti 
terhadap makna yang tersirat dalam wawancara, Data penelitian ini hanya berfokus pada penerimaan diri siswa dan pada yang dampak perceraian saja, Penelitian ini tidak membandingkan Informan dengan kondisi dan latar belakang yang sama, Penelitian dilakukan saat Pembatasan Sosial Berskala Besar (PSBB) yang disebabkan pandemi COVID-19. Peneliti tidak dapat bertemu langsung oleh Informan yang menyebabkan observasi partisipatif tidak dapat dilakukan, Sehingga peneliti tidak maksimal dalam melakukan penelitian dan juga memiliki waktu yang terbatas.

\section{KESIMPULAN}

Hasil dari penelitian ini menunjukkan penerimaan diri yang dimilliki oleh anak berhubungan dengan pola asuh yang orangtua lakukan kepada anak-anaknya dan bagaimana ia memandang keberhargaan dirinya sendiri untuk bangkit dari perceraian orangtua yang mereka hadapi. Jika pola asuh dari orangtua kepada anak cukup baik dan anak dijelaskan mengenai perceraian yang orangtua mereka harus tempuh, maka aspek dari penerimaan diri akan terpenuhi dengan baik. Karena perceraian orangtua tidak hanya berdampak pada pasangan suami-istri namun pada anak yang mereka lahirkan.

Pada penelitian ini masing-masing Informan memiliki pemicu tersendiri untuk bangkit sehingga keberadaan sekolah menjadi unsur yang berperan penting untuk menjadikan siswa lebih baik dalam memiliki peran sebagai anak, pelajar maupun anggota masyarakat.

Adapun penelitian ini menghasilkan saran :

Saran untuk Guru BK, agar guru BK memiliki program khusus untuk siswa yang mengalami perceraian orangtua seperti melakukan bimbingan dan konseling kelompok bagi siswa yang sangat terdampak terhadap perceraian orangtua sehingga mereka yang mengalami hal tersebut dapat mencurahkan perasaan serta menguatkan satu sama lain. Selain itu, guru BK dapat melakukan konseling individu agar siswa yang mengalami perceraian orangtua memiliki seseorang yang dapat ia percaya untuk bercerita atau berkeluh kesah dan tidak menyimpannya sendiri.

Saran untuk Orangtua, Masingmasing orangtua agar dapat lebih memahami posisi siswa sebagai pelajar sehingga mereka dapat fokus terhadap hal-hal yang ingin ia raih. Orangtua juga dapat meningkatkan komunikasi antara orangtua dan anak serta memberikan gambaran terhadap masa depan yang akan siswa hadapi sebagai makhluk sosial,siswa juga dapat dipersiapkan jika ia akan menghadapi posisi-posisi yang sulit dalam hidupnya. Sehingga ia tidak gegabah dalam mengambil keputusan.

Saran untuk Siswa, Siswa dapat mengenali kembali dirinya dan jangan sungkan jika ingin mendapat bantuan dari orang lain yang tepat untuk ia mintai bantuan seperti : Guru BK, wali kelas atau orang dewasa yang dekat dengan orangtuanya sehingga ia mendapatkan saran-saran yang benar dan hal yang seharusnya ia lakukan. Siswa juga dapat meningkatkan komunikasi dan lebih terbuka kepada orangtua mereka terhadap hal hingga masalah yang ia rasakan sehingga orangtua mereka dapat memahami dan mengenali yang siswa rasakan sebagai anak.

Peneliti Selanjutnya dapat melakukan penelitian mengenai penerimaan diri siswa dengan menggunakan variabel lainnya, melakukan penelitian korelasi atau eksperimen. 


\section{DAFTAR PUSTAKA}

Arikunto, S. (2006). Metode Penelitian Kualitatif. Jakarta: Bumi Aksara.

Badrujaman, A. (2015). Metode Penelitian Lanjutan dalam Bimbingan dan Konseling. Jakarta: Lembaga Pengembangan Pendidikan Universitas Negeri Jakarta.

Bernard, M. E. (Penyunt.). (2013). The Strength of Self-Acceptance Theory, Practice and Research. New York: Springer.

Bernard, M. E. (2013). The Strength of Self-Acceptance: Theory Practice and Research. . London: Springer.

Chase, S. E. (2005). Narrative Inquiry:

Multiple Lenses, Approaches,

Voices. In I. N. K. Denzin \& Y. S.

Lincoln (Eds.), The Sage handbook of qualitative research (pp. 651679). Sage Publications Ltd.

Creswell, J. W. (2007). Qualitative inquiry and research design : Choosing among five approaches. California: Sage Publications, Inc.

Dariyo, A. (2007). Psikologi perkembangan, anak tiga tahun pertama . Bandung: PT. Refina Aditama.

Elliot, G. C. (2009). Family Matters : The Importance of Mattering to Family in Adolescence. West Sussex: Blackwell Publishing.

Germer, C. K. (2009). The Mindful Path To Self-Compassion. United States of America: The Guilford Press.

Gunarsa, S. D., \& Gunarsa, Y. S. (2008). Psikologi Perkembangan Anak dan Remaja. Jakarta: PT. BPK Gunung Mulia.

Hurlock, E. B. (2006). Psikologi Perkembangan : suatu pendekatan sepanjang rentang kehidupan. Jakarta: Erlangga.

Krisnani, H., \& Farakhiyah, R. (2010). Meningkatkan Kemampuan Pengambilan Keputusan pada Remaja Akhir dengan Menggunakan Metode Reality Therapy. Share: Social Work Jurnal, 29-38.

Lestari, S. (2012). Psikologi Keluarga : Penanaman Nilai dan Penanganan Konflik dalam Keluarga. Jakarta: Kencana .

Machdan, D. M., \& Hartini, N. (2012). Hubungan Antara Penerimaan Diri dengan Kecemasan Menghadapi Dunia kerja pada Tunadaksa di UPT Rehabilitasi Sosial Cacat Tubuh Pasuruan. Jurnal Psikologi Klinis dan Kesehatan Mental, 79-85.

Marliani, R. (2016). Psikologi Perkembangan Anak dan Remaja. Bandung: CV Pustaka Setia.

Micucci, J. A. (2009). The adolescent in family therapy : harnessing the power of relationships (2nd ed.). New York: The Guilford Press.

Nasir, B. (2012). Faktor-faktor yang Mempengaruhi Perceraian di Kecamatan Sungai Kunjang Kota Samarinda. Jurnal Psikostudia Universitas Mulawarman, 31-48.

Puspitorini, I. (2019). Stop Perceraian Selamatkan Perkawinan. Temanggung: Desa Pustaka Indonesia. Polkinghorne, D. E. (1995). Narrative configuration in qualitative analysis. International Journal of Qualitative Studies in Education, 8(1), 5-23.

https://doi.org/10.1080/095183995 0080103

Simon, T., Nepo, M., Hanson, R., \& Neff, K. (2016). The Self-Acceptance 
Project: How to Be Kind and Compassionate Toward Yourself in Any Situation. Boulder: Soundstrue.

Syaifuddin, M., Turatmiyah, S., \& Yahanan, A. (2013). Hukum Perceraian. jakarta Timur: Sinar Grafika.

Verauli, R. (2018). Teenager 911. Jakarta Pusat: KataKita.

Wandberg, R. (2002). SelfAcceptance: building confidence. Mankato, Minnesota: Capstone Press.

Wangge, B. D., \& Hartini, N. (2013). Hubungan antara Penerimaan Diri dengan Harga Diri pada Remaja pasca Perceraian Orangtua. Jurnal Psikologi Kepribadian dan Sosial, 1-6. 